\title{
The Weakness and Strengthening of Academic Power in the University
}

\author{
Yongping He \\ Yibin University, Sichuan Province, P. R. China
}

\begin{abstract}
The academic power is the need of, teaching and finding profound knowledge of the University, also the need of ensuring the legitimate interests of the teachers. Our universities lacks the tradition of academic autonomy, academic power was weakened, severely affect the function of universities to play. Must reform university and strength the university's academic power.
\end{abstract}

KEYWORD: academic power; profound knowledge; academic organizations; professional

Because of the lack of academic autonomy tradition, university in our country usually is looked as the subordinate companies of the administrative department of education. University is usually performed by the administrative personnel to execute the decision of the competent department of the higher education. This leads to more power of the administrative personnel and less power of academic staff in the university.

\section{THE RATIONALITY OF ACADEMIC POWER}

The Key of a good university is that there are a group of outstanding academic staff. In 1931, Mei Yiqi said "the so-called university, not fore have big buildings, but fore have great master", when served as President of Tsinghai university. Academic staff should be the core strength of a university's, should have the reasonable power in university, this power is the academic power.

\subsection{The academic power is the need for teaching and finding advanced knowledge}

University is a place to study advanced knowledge, not only transmitting profound knowledge, but also discovering new advanced knowledge. "Knowledge discovery is never-ending, this determines autonomy of the academic power - allows scholars think independently and research free. Otherwise, the academic life would suffocate."[1] To ensure academic action go on wheels, we must award academic staff power. American Contemporary futurists Alwan Toffler also think that there are three kinds of power source: violence, wealth and knowledge.[2] Knowledge is one of the three major sources of power; the scholars who have advanced knowledge should have powers. The university is not only a knowledge organization, but also a place where "to research advanced knowledge", the advanced knowledge is the knowledge that "is still in the border between known and unknown," or "although known, but because they are too deep and mysterious, the ordinary people is difficult to grasp". University the academic staff are owners of profound knowledge, they are supposed to be the master of the university. When discussing "academic rule survived" in British university, Modi pointed out: "broadly, the popular reality can be summarized as" knowledge is power inside the university".[3] The power of the academic staff comes from the profound knowledge, the teacher known best of the content of profound knowledge, and most qualified to decide what courses should be settled and how to teach. In the university, academic staff should enjoy supreme power and status, academic staff as the owners of profound knowledge should have academic power.

\subsection{Academic power is the need for guaranteeing the interests of the scholars}

The administrators and academic staff are two different interest groups in the University, their interests sometimes is consistent and sometimes is conflicts. The scholars need actively fight for their own rights, cant hope to administrative personnel's selfless or wait administrators to maintain the rights of the scholars. Scholars must have its own power, only in this way can safeguard the rights and interests of their own well. 


\section{THE PERFORMANCE OF ACADEMIC POWER WEAKENING}

\subsection{Academic resources are preempted by administrative personnel}

Academic power is the power to guarantee the benefit of academic staff. The damage of academic staff interests is performance of Academic power weakening. Administrative personnel take academic resources, this leads to harm of the teachers' rights and interests and destroys the academic principles of fair competition and hinder the real academic research activities. In the universities, the administrative personnel using the power to possession all kinds of academic resources: various academic title preempted by administrative personnel, in 2009 the ministry of education named 100 famous teachers, more than 90 are in leadership positions, not ordinary teachers.[4] In A well-known "985 university", the principal is voted as the most popular "teacher" by students, but the role of the principal is not "the first as a teacher". A variety of research projects have also been possessed by administrative personnel, generally teachers are difficult to get, Teachers cannot compete with administrative personnel who have power when applying for research projects.

\subsection{Academic organization is marginalized and administrative}

Marginalization of academic organization is performance of Academic power weakening. In China, academic organization does not have decision-making power, academic policy is not laid down by academic organization, also do not need to be passed by the academic organization. Administrative agencies lay down various academic regulations, whether those regulations are reasonable or not, the academic staff need to be unconditional obedience. academic organization do not form its own system, dismembered by administrative organs, and technology such as the scientific research committee belonging to Science and Technology Department, teaching steering committee affiliated to teaching affairs department and so on, academic organization dismembered inevitably leads to the weakness of academic power. At the same time, the academic organization are administrative: a large number of administrative staff is filled with academic organizations this leads to administrative personnel have both administrative power and academic power, form the "scholar-tyrant "who is both officials and scholars, seriously influence academic ecology.

\section{THE HARM OF ACADEMIC POWER WEAKENING}

\subsection{The value orientation to officials}

The weakness of academic power makes some scholar to "officer" not to "scholars "in the university. The generalization of administrative power result the highly respect of executive leadership, and professor can't get a due respect. This makes university not as university but as a government and make a lot of people try to seek the administrative leadership positions. There are 40 professors compete for a director in Shenzhen.[5] A lot of people who gain successful in academic career requires administrative leadership positions, the university leaders tends to use "official" in order to retain outstanding scholars. This does not only waste the rare resources of academic manpower but also lead to administrative bloated. There is 1872601 staff in regular institutions of higher education in our country in 2006, of which only 1075989 people fulltime teachers accounted for only 58\%.[6]

\subsection{Influence the academic staff's work enthusiasm}

The weakness of academic power influences the work of teaching and researching. The academic power is too small to attract outstanding scholars to the administrative positions, to makes the college has a large of "officer" professor, and this is the serious waste of academic resources. Administrative power is so big that generally scholar's right cannot be guaranteed and be lack of academic development, this seriously influence academic staff enthusiasm for teaching and researching, in end affects the efficiency and quality of university teaching and researching activities.

In a word, the weakness of academic power makes university deviate from the characteristics of its academic organization, makes the university don't like university but as a government agency, influence normal play of the function of teaching, scientific researching and social servicing and cultural hesitating and innovating of university.

\section{COUNTERMEASURES TO STRENGTHEN THE ACADEMIC POWER}

College is not purely academic community today, there are scholars and administrative personnel in the university, and they are party of the university and should exercise their respective powers to complete their responsibilities. The weakness of academic power in our country's university do harm to the university's function, we must strengthen academic power in the university. 


\subsection{Solid the academic organization}

Ascension is the basic way to improve the academic power is establishing perfect academic committee. The first is to make academic committee to form a system of organization. Academic organization of the university in our country are scattered by administrative agencies: such as teaching steering committee is set in teaching affairs office, Research Councils is set in science and technology department. This cause the academic organization's political trending. In foreign countries, the academic committee is an integral part of university's governance structure and is an independent system. The academic committee has many special committees. The academic committee of Salford University has four basic special committees: Academic review and management committee; Academic programs and partners committee; improve learning and teaching committee; Research council. The academic senate of California University has 24 special committees.[7]So, it is important to form a unified academic committee organization to exercise the academic power. Only this can prevent the administrative power interference the academic power. Designate academic organization and administrative organization respective power and give academic organization to exercise the corresponding academic power. Give academic organization the power to set and review of system of teaching activities, scientific research, and discipline construction, course offering to make scholars as academic policymakers or final decision makers and let scholars reserve the final say over the university academic system.

\subsection{Down academic organization power}

Academic power comes from knowledge, and knowledge in the university is special and very different between disciplines, an expert in the field may be in the dark of the development of another field, so scholars are experts within specific subject, specific knowledge. They know little or even fundamental do not understand the knowledge of different disciplines. So, the power of the academic staff only limited to their own professional, beyond their own professional, they are no longer the academic authority and can't evaluation the academic staff of other professional academic. The top-down power relations in the university makes the university have big power at the school level and small power in departments, this make the university academic power weaken. Strengthening academic power must down the university's power to strengthen the bottom academic power, to concentrate more power in the academic committee of departments, put the power of evaluating academic level of teachers and the students' academic performance to the academic committee of departments, academic committee of school reserve limited power as to decide discipline development of the university, etc.

\subsection{Pure academic organization}

Perfecting academic committee should standardize the generation mechanism of the academic committee members. There is too many administrative staff in academic committee in the university in our country. Which make it easy for the academic power is dominated by administrative power. In the countries such as Britain and America, there are strict rules about the composition of the academic committee, in Japanese universities, it is the education research council to exercise the academic power, and every university has strict rules of method to produce the committee members. Perfecting academic committee should regulate the mechanism of producing the academic committee member; determine the proportion of administrative staff and academic staff in the academic committee, let non-executive academic staff as the main body of the academic committee.

University academic power is the need of internal logic, only to ensure the power and interest of scholars can let scholars research and teach fully and dignified, and then let the scholars return to peace from impetuous. Only the return of university academic power can make the university set sail toward the right direction, and make the university become a temple of knowledge.

\section{REFERENCES}

[1] Li Guoli. The characteristics of the academic power and operation mechanism. Journal Of academia No.1, pp. 188192, 2004.

[2] Alvin Toffler (1991).Power shift. Beijing: The central party school publishing house. pp19.

[3] Clark Burton R (1994). The higher education system: Academic organization in cross-national perspective. Hangzhou: Hangzhou University press. pp174.

[4] Zhu Qingshi. Build a university without administerization, Southern people weekly, 2010-1-8.

[5] http://www.chinanews.com.cn/edu/kong/news/2008/0907/1373577.shtml.

[6] The national bureau of statistics of the People's Republic of China (2007). China education yearbook (2007). Beijing: China statistics press. pp96.

[7] http://www.universityofcalifornia.edu/senate/committees.p hp. 